\title{
SITUATION-BASED LEARNING UNTUK MENINGKATAN KEMAMPUAN CREATIVE PROBLEM SOLVING MATEMATIS SISWA SD
}

\author{
Isrok'atun \& Tiurlina \\ Prodi PGSD Universitas Pendidikan Indonesia Kampus Serang \\ Jl. Ciracas No. 18 Serang Banten \\ Email: isrokatun@gmail.com
}

\begin{abstract}
In general, the learning activity that occurs is more emphasis on the process of learning to learn to answer questions rather than learn how to present the question. Students do not learn how to bring mathematical problems (problem posing) are of interest to them, from a mathematical situation faced. This results in the problem of finding the weak ability of students, so the ability of the idea of finding and problem solving students also weak. Idea finding, problem finding and problem solving is an aspect of the ability of Creative Problem Solving (CPS) mathematically. Therefore, the ability of CPS becomes very necessary to be developed in the learning of mathematics. For this purpose, the necessary mathematics learning more digging ability in presenting the problem and resolve the concerns raised by the students themselves, using the Situation-Based Learning (SBL). This study used a quasi-experimental. The results of the study concluded that an increase in the ability to obtain mathematical CPS students getting SBL better learning than students who received conventional learning significantly. CPS strongest mathematical ability of the students are in fact finding aspects, while CPS mathematical abilities of the students in the weakest aspect of finding acceptance. Keywords: mathematical situation, a mathematical problem, creative problem solving mathematical, situation-based learning.
\end{abstract}

ABSTRAK

Pada umumnya kegiatan pembelajaran yang terjadi adalah proses pembelajaran lebih menekankan pada belajar menjawab pertanyaan daripada belajar bagaimana untuk menyajikan pertanyaan. Siswa tidak belajar bagaimana memunculkan permasalahan matematis (problem posing). Hal ini mengakibatkan lemahnya kemampuan problem finding, sehingga kemampuan idea finding dan problem solving siswa juga lemah. Idea finding, problem finding, dan problem solving merupakan aspek kemampuan Creative Problem Solving (CPS) matematis. Oleh sebab itu, kemampuan CPS menjadi hal yang sangat perlu untuk dikembangkan. Untuk tujuan tersebut, maka dilakukan pembelajaran dengan menggunakan Situation-Based Learning (SBL). Metode penelitian didesain menggunakan quasi eksperimen. Kelompok eksperimen mendapatkan perlakuan berupa pembelajaran SBL dan kelompok kontrol mendapatkan pembelajaran konvensional. Hasil penelitiannya adalah adanya peningkatan kemampuan CPS matematis siswa yang mendapat pembelajaran SBL lebih baik daripada siswa yang mendapat pembelajaran konvensional secara signifikan. Kemampuan CPS matematis terkuat yang dimiliki siswa yaitu pada aspek fact finding, sementara kemampuan CPS matematis terlemah yang dimiliki siswa pada aspek acceptance finding.

Kata kunci: situasi matematis, masalah matematis, creative problem solving matematis, situation-based learning.

PENDAHULUAN Berpikir merupakan suatu kegiatan mental yang dialami seseorang jika mereka dihadapkan pada suatu masalah atau situasi yang harus dipecahkan. Akan tetapi, tidak semua orang mempunyai pandangan masalah yang sama dengan orang lain terhadap suatu situasi. Hal ini dikarenakan, pengetahuan yang dimiliki oleh seseorang sangat mempengaruhi cara pandang terhadap suatu situasi tersebut. Bisa saja, suatu situasi 
mengandung masalah yang sangat krusial bagi seseorang, tetapi bagi orang lain yang masih satu kepentingan bahkan tidak menyadari bahwa hal tersebut dapat menjadi masalah besar juga bagi dirinya. Dengan kata lain, suatu situasi bisa jadi masalah rumit bagi seseorang, tetapi bisa jadi bukan menjadi masalah bagi orang lain.

Suatu situasi dikatakan masalah bagi seseorang jika ia menyadari keberadaan situasi tersebut, mengakui bahwa situasi tersebut memerlukan tindakan dan tidak dengan segera dapat menemukan pemecahannya (Newell \& Simon, 1972; Yee, 2002; Hamzah, 2003; Dindyal, 2009; Kaur \& Yeap, 2009). Masalah adalah sesuatu yang membutuhkan tindakan, tetapi sulit atau pun membingungkan (Schoenfeld, 1992). Hayes (dalam Hamzah, 2003) mendukung pendapat tersebut dengan mengatakan bahwa, suatu masalah merupakan kesenjangan antara keadaan sekarang dengan tujuan yang ingin dicapai, sementara kita tidak mengetahui apa yang harus dikerjakan untuk mencapai tujuan tersebut. Dengan demikian, masalah dapat diartikan sebagai pertanyaan yang harus dijawab pada saat itu, sedangkan kita tidak mempunyai rencana solusi yang jelas.

Masalah menurut Treffinger, Isaksen, dan Dorval (dalam Steiner, 2009) adalah '....any important, open ended, and ambiguous situation for which one wants and needs new options and a plan for carrying a solution successfully'. Suatu masalah dikatakan bersifat open ended, karena memberikan berbagai pilihan jawaban, atau dengan kata lain jawabannya tidak tunggal, atau satu solusi tetapi untuk mendapatkannya dapat ditempuh berbagai cara. Dengan demikian, tidak bertumpu pada mana jawaban yang benar, tetapi lebih pada bagaimana proses menjawabnya, dan bisa jadi semua jawaban tersebut adalah benar. Sementara suatu situasi dikatakan ambigu di sini dapat diartikan bahwa situasi tersebut tidak hanya dapat dimaknai secara tunggal, tetapi mengandung berbagai pengertian, sehingga dalam penyelesaiannya pun membutuhkan berbagai solusi, dalam rangka memaknai arti situasi tersebut.

Seseorang dapat memecahkan suatu permasalahan tentunya jika memiliki kemampuan pemecahan masalah yang cukup. Menurut Utari-Sumarmo (dalam Soekisno, 2002), pentingnya pemilikan kemampuan pemecahan masalah matematis pada siswa adalah bahwa kemampuan pemecahan masalah merupakan tujuan pengajaran matematika, bahkan sebagai jantungnya matematika. Sedangkan dalam Kurikulum KTSP (Depdiknas, 2007), juga disebutkan bahwa tujuan pembelajaran matematika adalah untuk mengembangkan kemampuan pemecahan masalah.

Akan tetapi dalam pembelajaran di kelas, guru banyak bertanya kepada siswa dengan frekuensi yang tinggi tetapi dengan level yang rendah. Metode pembelajaran yang digunakan lebih pada belajar untuk menjawab, daripada belajar untuk menyajikan permasalahan sehingga tidak mengembangkan kesadaran siswa terhadap masalah dan kemampuan dalam problem solving (menyelesaikan masalah). Oleh sebab itu, kemampuan Creative Problem Solving (CPS) menjadi hal yang sangat perlu untuk dikembangkan dalam pembelajaran matematika. Kemampuan CPS matematis adalah kemampuan matematis yang terdiri atas kemampuan: 1) objective finding; 2) fact finding; 3) problem finding; 4) idea finding; 5) solution finding; dan 6) acceptance finding. Untuk setiap aspek kemampuan tersebut, siswa memulainya dengan aktivitas berpikir divergen dan diakhiri dengan aktivitas berpikir konvergen (Ellyn, 1995; Mitchell \& Kowalik, 1999; Proctor, 2007; Isrok'atun, 2012a).

Guna mengembangkan kemampuan tersebut, perlu kiranya melakukan pembelajaran matematika yang lebih menggali kemampuan siswa dalam menyajikan masalah serta menyelesaikan permasalahan yang dimunculkan oleh siswa itu sendiri secara kreatif. Salah satu pembelajaran yang dapat mengatasi permasalahan ini, yaitu dengan menggunakan pembelajaran Situation-Based Learning (SBL). Proses pembelajaran SBL ini dapat diterapkan melalui bahan ajar yang didesain berdasarkan karakteristik situation-based learning, supaya siswa lebih mengembangkan kreativitas dan produktivitas berpikirnya. Tugas guru di sini lebih berperan sebagai motivator dan fasilitator.

Adapun permasalahan yang akan dikemukakan pada penelitian ini adalah: 'Apakah peningkatan kemampuan CPS matematis siswa yang mendapat pembelajaran SBL lebih baik daripada siswa yang mendapat pembelajaran konvensional?' 


\section{Situation-Based Learning (SBL)}

Situation-Based Learning merupakan pendekatan baru yang kuat dan fleksibel dalam membangun paradigma pembelajaran yang konstruktivistik (Tarek, Thomas, Hermann, \& Maja, 2000). Menurut Lave; Lave dan Wenger; Greeno, Smith, dan Moore (dalam Anderson, Reder, \& Simon, 1996), hal ini karena ada banyak hal yang dapat siswa pelajari dari sebuah situasi, tempat di mana ia belajar. Tujuan dari SBL adalah untuk mengembangkan kemampuan siswa dalam problem posing, problem understanding, dan problem solving dari sudut pandang matematika.

Situation-Based Learning adalah pembelajaran yang terdiri dari 4 tahapan proses pembelajaran, yaitu 1) creating mathematical situations; 2) posing mathematical problem; 3) solving mathematical problem; dan 4) applying mathematics, sebagaimana digambarkan dalam diagram berikut (Xia, LÜ, Wang, \& Song, 2007; Xia, LÜ, \& Wang, 2008; Isrok'atun, 2012b; Isrok'atun, 2012c).

\section{SITUATION-BASED LEARNING}

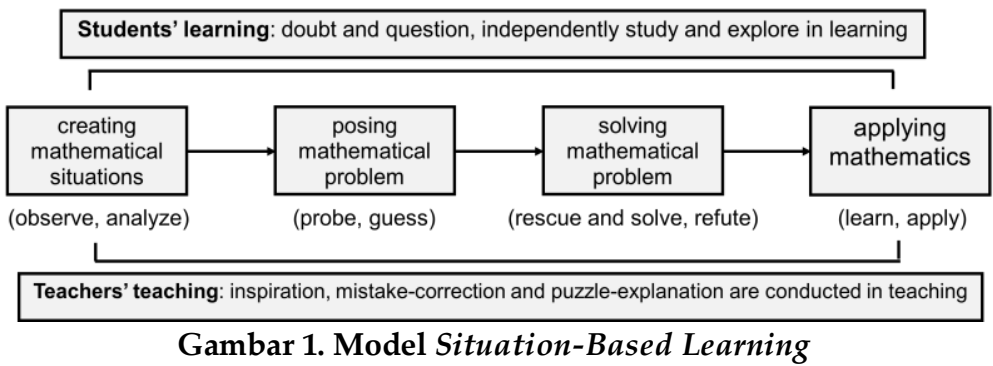

Creating mathematical situations adalah prasyarat. Posing mathematical problem adalah inti, sedangkan solving mathematical problem adalah tujuan, sementara applying mathematics adalah penerapan proses pembelajaran terhadap situasi baru.

Adapun langkah-langkah pembelajaran SBL adalah sebagai berikut (Isrok'atun, 2012b).

1) Guru mengkreasi sebuah situasi

Pada langkah ini, guru mengkreasi suatu situasi matematis. Dari situasi matematis tersebut, diharapkan akan muncul berbagai pertanyaan dari siswa, tentunya pertanyaan yang bersifat matematis, melalui kegiatan mengobservasi dan menganalisis. Situasi di sini dapat dimulai dengan situasi yang sederhana terlebih dahulu, yang kemudian berkembang pada situasi yang lebih kompleks.

2) Siswa menyajikan problem matematis

Dengan kegiatan menyelidiki dan menebak, siswa melakukan kegiatan problem posing matematis. Hal ini adalah guna meningkatkan kesadaran siswa akan adanya suatu masalah dari situasi yang dihadapi. Tugas guru di sini adalah menempatkan masalah-masalah yang dimunculkan siswa ke dalam level-level yang tertentu, sesuai dengan tingkat kesulitannya.

3) Siswa melakukan solving problem matematis Dari permasalahan yang dapat dikemukakan oleh siswa pada langkah pembelajaran ke-2, guru bersama siswa memilah-milah level masalah yang ada, masalah manakah yang sekiranya perlu ditindak lanjuti untuk diselesaikan. Masalah yang diselesaikan diawali dari masalah sederhana sampai pada masalah yang memiliki permasalahan yang kompleks. Sebagai bahan pembelajaran, tujuan utama di sini adalah memunculkan masalah yang memerlukan penyelesaian dengan kemampuan CPS matematis sehingga siswa dapat menemukan kembali konsep/rumus/aturan matematika. Guru di sini berperan untuk membimbing, mengarahkan, dan merangsang siswa dengan teknik scaffolding.

4) Applying mathematics

Langkah pembelajaran applying mathematics adalah langkah kegiatan siswa dalam menerapkan konsep/rumus/aturan matematika yang baru saja ditemukan dari kegiatan solving problem matematis, pada 
permasalahan maupun situasi yang baru/berbeda. Tujuan dari kegiatan ini adalah siswa dapat memahami bahwasanya konsep/rumus/aturan matematika hakikatnya sering mereka jumpai dalam kehidupan sehari-hari.

\section{Pembelajaran Konvensional}

Pembelajaran konvensional yang dimaksud pada penelitian ini adalah model pembelajaran yang biasa digunakan oleh guru kelas dalam proses pembelajaran sedemikian hingga peranan siswa masih kurang, pengajaran lebih berpusat pada guru, dan proses belajar lebih mengutamakan pada metode ekspositori.

\section{Kemampuan CPS Matematis Siswa}

Kemampuan CPS matematis mempunyai 6 aspek, setiap aspek dimulai dari aktivitas div/ergen dan diakhiri dengan aktivitas konvergen. Aspek kemampuan dalam proses CPS matematis adalah sebagai berikut (Ellyn, 1995; Mitchell \& Kowalik, 1999; Proctor, 2007; Isrok'atun, 2012a). Osborn-Parnes creative problem solving process:

(1) Objective finding
Upaya mengidentifikasi situasi ke dalam bentuk yang menantang.

(2) Fact finding

Upaya mengidentifikasi semua data-data yang masih berkaitan dengan konteks situasi, mencari dan mengidentifikasi informasi yang tidak terdapat pada situasi tetapi penting.

(3) Problem finding

Upaya mengidentifikasi semua statement problem yang mungkin, kemudian memilahmilah mana yang penting.

(4) Idea finding

Upaya mengidentifikasi beberapa solusi dari statement problem, yang mungkin.

(5) Solution finding

Menggunakan daftar solusi yang telah dipilih pada tahap idea finding, memilih solusi yang terbaik untuk menyelesaikan problem.

(6) Acceptance finding

Upaya meningkatkan daya dukung, melakukan rencana aksi, dan mengimplementasikan solusi.

Untuk penjelasan lebih detail mengenai alur proses berpikir CPS, dapat dilihat pada gambar berikut (Isaksen \& Treffinger, 1985):

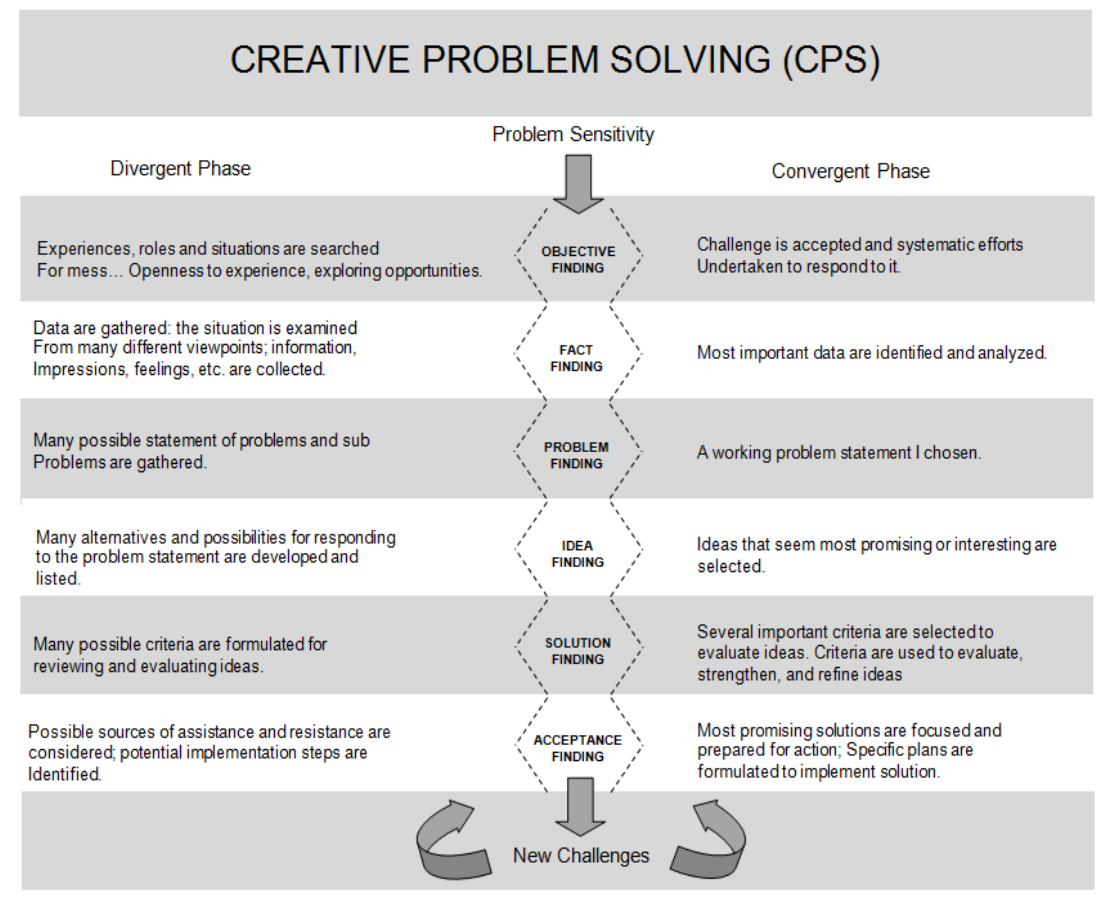

Gambar 2. Alur Proses Berpikir CPS

\section{METODE}

\section{Tujuan}

Penelitian ini bertujuan untuk mengetahui apakah peningkatan kemampuan CPS matematis siswa yang mendapat pembelajaran SBL lebih baik daripada siswa yang mendapat pembelajaran konvensional. 


\section{Sampel Penelitian}

Populasi pada penelitian ini adalah seluruh siswa SD pada kategori peringkat sedang di Propinsi Banten. Terpilihlah SD N 9 Kota Serang sebagai subyek dalam penelitian ini.

Sampel pada penelitian ini dipilih siswa SD kelas 5. Siswa kelas 5 dipandang sudah dapat diajak berpikir lebih tinggi (kemampuan berpikir matematis tingkat tinggi, yaitu kemampuan CPS matematis) dibanding kelas-kelas sebelumnya, dan sedang tidak disibukkan dengan persiapan menghadapi Ujian Nasional (UN). Dari 2 kelas paralel yang ada di sekolah tersebut, setelah dipilih secara acak menghasilkan kelas 5A sebagai kelas eksperimen dan kelas $5 \mathrm{~B}$ sebagai kelas kontrol.

Ditetapkan bahwa, kelas 5A (47 siswa) sebagai kelas eksperimen, dengan mendapatkan pembelajaran SBL dan kelas 5B (47 siswa) sebagai kelas kontrol dengan mendapatkan pembelajaran konvensional.

\section{Desain Penelitian}

Penelitian ini adalah penelitian quasi eksperimen dengan mengggunakan kelompok eksperimen dan kelompok kontrol yang dikenal dengan pretest-postest control group design (Fraenkel \& Wallen, 1990; Ruseffendi, 1998; Sugiyono, 2011). Kelompok eksperimen mendapatkan perlakuan berupa pembelajaran SBL dan kelompok kontrol mendapatkan pembelajaran konvensional. Adapun desain penelitian ini, dsebagai berikut.

$$
\begin{array}{lll}
\mathrm{O} & \mathrm{X} & \mathrm{O} \\
\mathrm{O} & & \mathrm{O}
\end{array}
$$

Keterangan:

$$
\mathrm{O}=\text { pretes }=\text { postes } \text { kemampuan }
$$

CPS matematis

$$
\mathrm{X}=\text { pembelajaran SBL }
$$

\section{HASIL DAN PEMBAHASAN}

Setelah kedua kelas diberi perlakuan berbeda, yaitu pembelajaran SBL di kelas eksperimen dan pembelajaran konvensional di kelas kontrol, maka diperoleh hasil pencapaian kemampuan CPS matematis sebagai berikut.

Tabel 1. Kemampuan CPS Matematis

\begin{tabular}{ccccccccc}
\hline \multirow{2}{*}{ Pembelajaran } & \multirow{n}{*}{$\boldsymbol{n}$} & \multicolumn{2}{c}{ Pretes } & \multicolumn{2}{c}{ Postes } & \multicolumn{2}{c}{ Gain } & \multirow{2}{*}{ Kategori } \\
\cline { 3 - 8 } & & Rerata & S.B & Rerata & S.B & Rerata & S.B & Gain \\
\hline SBL & 47 & 16,32 & 11,58 & 32,91 & 14,38 & 0,24 & 0,16 & rendah \\
Konvensional & 47 & 16,21 & 7,82 & 24,66 & 9,56 & 0,12 & 0,12 & rendah \\
\hline
\end{tabular}

Dari tabel di atas, terlihat bahwa peningkatan kemampuan CPS matematis siswa yang mendapatkan pembelajaran SBL dengan rerata peningkatan 0,24 , lebih baik daripada siswa yang mendapatkan pembelajaran konvensional yaitu dengan rerata peningkatan 0,12 untuk rentang nilai peningkatan $0-1$.

Kedua kelompok mengalami peningkatan (gain) kemampuan CPS matematis yang berarti. Kelompok siswa yang mendapatkan pembelajaran SBL mengalami peningkatan kemampuan CPS matematis $(0,24)$ pada kategori rendah sementara peningkatan kemampuan CPS matematis kelompok yang mendapatkan pembelajaran konvensional sebesar 0,12 berada pada kategori rendah, setengah dari peningkatan yang dicapai oleh kelas eksperimen.

Untuk dapat mengatakan peningkatan pada kelompok mana yang lebih baik, apakah pada kelompok siswa yang mendapatkan pembelajaran SBL ataukah pada kelompok siswa yang mendapatkan pembelajaran konvensional,

\begin{tabular}{|c|c|c|c|c|c|c|}
\hline \multirow[b]{2}{*}{ Pembelajaran } & \multirow[b]{2}{*}{$n$} & \multicolumn{2}{|c|}{ Gain } & \multicolumn{2}{|c|}{ Uji Statistik } & \multirow{2}{*}{$\begin{array}{c}\text { Uji Beda Rerata } \\
\text { (Uji Mann- } \\
\text { Whitney) }\end{array}$} \\
\hline & & Rerata & S.B & Normalitas & Homogenitas & \\
\hline SBL & 47 & 0,24 & 0,16 & Normal & Varians tidak & Kedua rerata \\
\hline
\end{tabular}
maka dilakukan uji statistik. Adapun hasil uji statistik yang dimaksud, sebagai berikut:

Tabel 2. Ringkasan Uji Statistik terhadap Gain Kemampuan CPS Matematis 


$\begin{array}{llllcll}\text { Konvensional } & 47 & 0,12 & 0,12 & \begin{array}{c}\text { Tidak } \\ \text { normal }\end{array} & \text { sama } & \text { berbeda }\end{array}$

Keterangan: $\alpha=0,05$

Dari tabel di atas dapat dijelaskan,bahwa, peningkatan kemampuan CPS matematis kelompok siswa yang mendapatkan pembelajaran SBL $(0,24)$ lebih baik daripada kelompok siswa yang mendapatkan pembelajaran konvensional $(0,12)$ secara signifikan.
Penjelasan bagaimana perolehan skor siswa di kelas eksperimen terhadap kemampuan CPS matematis jika dilihat per aspek, serta pada aspek manakah kemampuan CPS matematis siswa adalah terkuat atau bahkan terlemah, yaitu sebagai berikut.

Tabel 3. Kemampuan CPS Matematis Siswa di Kelas Eksperimen Dilihat dari per Aspek CPS Matematis

\begin{tabular}{ccccccc}
\hline $\begin{array}{c}\text { Aspek CPS } \\
\text { Matematis }\end{array}$ & O & F & P & I & S & A \\
\hline $\begin{array}{c}\text { Frekuensi } \\
\text { kemunculan }\end{array}$ & 5 & 5 & 3 & 5 & 4 & 2 \\
Skor maks & 3 & 3 & 4 & 4 & 4 & 4 \\
Skor yang diperoleh: & - & - & - & - & - & - \\
Soal no. 1 & 51 & 49 & - & 51 & 42 & 36 \\
Soal no. 2 & 36 & 20 & 23 & 23 & - & - \\
Soal no. 3 & 56 & 56 & 66 & 59 & 54 & - \\
Soal no. 4 & 41 & 38 & - & 38 & 24 & 22 \\
Soal no. 5 & 10 & 73 & 6 & 45 & 45 & - \\
Jumlah & 194 & 236 & 95 & 216 & 165 & 58 \\
\% perolehan skor per & 28 & 33 & 17 & 23 & 22 & 15 \\
aspek & & & & & & \\
\hline
\end{tabular}

Tabel di atas menjelaskan persentase perolehan skor pada kemampuan CPS matematis siswa dilihat per aspeknya. Aspek CPS matematis terkuat yang dimiliki siswa adalah pada aspek fact finding. Fact finding merupakan aspek kemampuan CPS matematis pada upaya mengkoleksi data terkait tentang problem dan mengeksplorasi fakta-fakta dari situasi, dengan indikator kemampuan, yaitu mampu membuat keterkaitan; mencari hubungan; membuat koneksi terkait tentang problem dan menguraikan; merinci; menyusun; mencari informasi yang tersembunyi terkait fakta yang terkandung pada situasi. Sementara aspek CPS matematis terlemah yang dimiliki siswa adalah pada aspek acceptance finding. Acceptance finding merupakan aspek kemampuan CPS matematis pada upaya meningkatkan daya dukung jawaban yang diperoleh, melakukan rencana aksi penyelesaian, serta mengimplementasikan solusi, dengan indikator kemampuan yaitu mampu mengembangkan rencana aksi penyelesaian, mempertimbangkan rencana-rencana yang mendukung perolehan jawaban sebelumnya, serta mengungkapkan rencana dukungan jawaban tersebut.

\section{SIMPULAN}

Pembelajaran SBL adalah pembelajaran yang terdiri dari 4 tahapan proses pembelajaran, yaitu 1) creating mathematics situations (prasyarat); 2) posing mathematical problem (inti); 3) solving mathematical problem (tujuan); dan 4) applying mathematics (penerapan).

Pembelajaran SBL ini dapat menjadi alternatif pembelajaran dalam upaya untuk meningkatkan kemampuan CPS matematis siswa SD. Dari masalah-masalah yang berhasil siswa kemukakan, kemudian dengan bimbingan guru ia selesaikan dengan teknik-teknik pemecahan masalah matematis. Hal ini tidak lain adalah dalam rangka untuk mengurangi 
ketidakseimbangan akan kemampuan problem prosesnya, dapat digambarkan sebagai berikut. posing dan problem solving siswa. Adapun alur

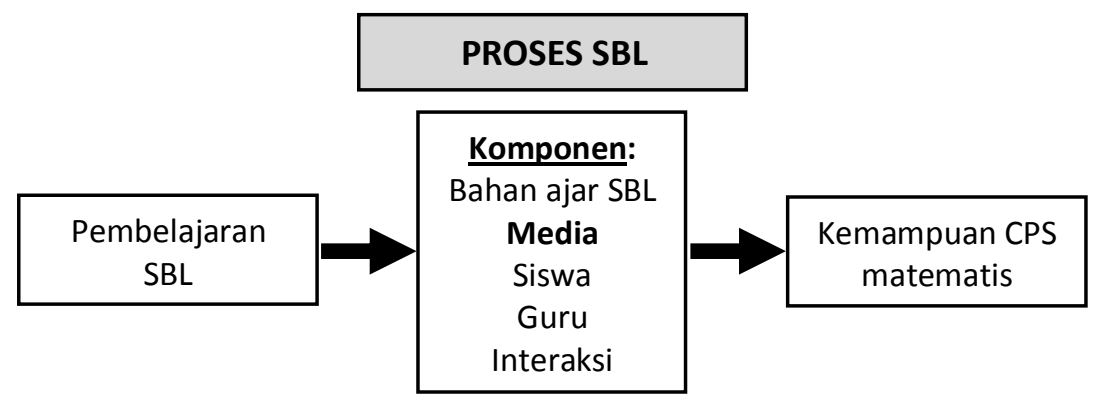

Gambar 3. SBL untuk Meningkatkan Kemampuan CPS Matematis Siswa SD

\section{REFERENSI}

Anderson, J.R., Reder, L.M., dan Simon, H.A. (1996). "Situated Learning and Education". Journal of Educational Researcher. 25, (4), 511.

Depdiknas (2007). Kajian Kebijakan Kurikulum Mata Pelajaran Matematika. Jakarta: Badan Penelitian dan Pengembangan, Puskur.

Dindyal, J. (2009). Mathematical Problems for the Secondary Classroom. Dalam Berinderjeet Kaur, Yeap Ban Har, dan Manu Kapur (editor), Mathematical Problem Solving. Toh Tuck Link: World Scientific Publishing Co. Pte. Ltd.

Ellyn, G. (1995). Creative Problem Solving. Illinois: The Co-Creativity Institute.

Fraenkel, J.C. dan Wallen, N.E. (1990). How to Design and Evaluate Research in Education. New York: McGraw-Hill Inc.

Hamzah (2003). Meningkatkan Kemampuan Memecahkan Masalah Matematika Siswa Sekolah Lanjutan Tingkat Pertama Negeri di Bandung melalui Pendekatan Pengajuan Masalah. Bandung: Disertasi SPs UPI. Tidak diterbitkan.

Isaksen, S.G. dan Treffinger, D.J. (1985). Creative Problem Solving: The Basic Course. New York: Bearly Limited.

Isrok'atun (2012a). “Creative Problem Solving (CPS) Matematis". Prosiding Seminar Nasional Kontribusi Pendidikan Matematika dan Matematika dalam Membangun Karakter Guru dan Siswa. Yogyakarta: Jurusan Pendidikan Matematika FMIPA UNY.

Isrok'atun (2012b). “Meningkatkan Kesadaran Siswa terhadap Adanya Masalah Matematis melalui Pembelajaran Situated Creation and Problem-Based Instruction (SCPBI)". Prosiding Seminar Nasional Pendidikan Matematika XX, Let's Have Fun with Mathematics. Yogyakarta: Himpunan Mahasiswa Jurusan Pendidikan Matematika FMIPA UNY.

Isrok'atun (2012c). "Situation-Based Learning untuk Meningkatkan Kesadaran Siswa terhadap Adanya Masalah Matematis". Jurnal Penelitian dan Pembelajaran Matematika. V, (2), 61-68.

Kaur, B dan Yeap, B.H. (2009). Mathematical Problem Solving in Singapore Schools. Dalam Berinderjeet Kaur, Yeap Ban Har, dan Manu Kapur (editor), Mathematical Problem Solving. Toh Tuck Link: World Scientific Publishing Co. Pte. Ltd.

Mitchell, W.E dan Kowalik, T.F. (1999). Creative Problem Solving. NUCEA: Genigraphict Inc.

Newell, A. \& Simon, H. (1972). Human Problem Solving. Englewood Cliffs, NJ: Prentice Hall.

Proctor, T. (2007). Theories of Creativity and the Creative Problem Solving Process. [Online]. Tersedia di: http://www.google.co.id/search?q=proctor. [12 April 2012].

Ruseffendi, H.E.T. (1998). Statistika Dasar untuk Penelitian Pendidikan. Bandung: IKIP Bandung Press.

Schoenfeld, A.H. (1992). Learning to Think Mathematically: Problem Solving, Metacognition, and Sense-Making in Mathematics. New York: MacMillan.

Soekisno, B.A. (2002). Kemampuan Pemecahan Masalah Matematika Siswa dengan Strategi 
Heuristik. Bandung: Tesis SPs UPI. Tidak diterbitkan.

Steiner, G. (2009). "The Concept of Open Creativity: Collaborative Creative Problem Solving for Innovation Generation-a Systems Approach". Journal of Business and Management. 15, (1), 5-33.

Sugiyono (2011). Metode Penelitian Kombinasi (Mixed Methods). Bandung: Alfabeta.

Tarek, A.U., Thomas, D., Hermann, M., dan Maja, P. (2000). Situation Learning or What Do Adventure Games and Hypermedia Learning have in Common. [Online]. Tersedia di: http://www. google. co.id/ search? $\mathrm{q}=$ situations-based+learning. [17 April 2012].
Xia, X., LÜ, C., Wang, B., dan Song, Y. (2007). "Experimental Research on Mathematics Teaching of "Situated Creation and Problembased Instruction" in Chinese Primary and Secondary School". Journal of Front. Educ. 2, (3), 366-377.

Xia, X., LÜ, C., dan Wang, B. (2008). "Research on Mathematics Instruction Experiment Based Problem Posing". Journal of Mathematics Education. 1, (1), 153-163.

Yee, F.P. (2002). Using Short Open-ended Mathematics Questions to Promote Thinking and Understanding. [Online]. Tersedia di: http:// math.unipa. it/ grim/SiFoong.PDF. [11 April 2012]. 